\title{
ASSESSMENT OF SOLID WASTE MANAGEMENT IN BHAKTAPUR MUNICIPALITY
}

\author{
Amit Shankar Ranjit ${ }^{1}$, Ronish Shakya ${ }^{2}$, Sushila Gwachha ${ }^{3}, \operatorname{Razim}_{\text {Ganesh }}{ }^{1}$, Meera \\ Prajapati $^{3}$, Puna Bhaila ${ }^{3}$, Indu Duwal ${ }^{4}$ \\ ${ }^{I}$ Department of Civil Engineering, Khwopa Engineering College, Bhaktapur, Nepal \\ ${ }^{2}$ Oracle Nepal, Kathmandu, Nepal \\ ${ }^{3}$ Department of Environmental Science, Khwopa College, Bhaktapur, Nepal \\ ${ }^{4}$ Department of Architecture, Khwopa Engineering College, Bhaktapur, Nepal
}

\begin{abstract}
Bhaktapur Municipality has been performing better to keep the city clean. However, scarcity of space for the land filling of the solid waste and proper segregation of waste at the source has been a hurdle for the Municipality. This paper aims to determine solid waste generation rate and to analyze overall situation of solid waste management of Bhaktapur Municipality. However, the data will not represent the seasonal and occasional variations. Additionally, waste from street-sweeping and large-scale institutional and commercial components of the Municipality has not been assessed. Arkin and Colton (1963) was referred for the sample size determination. Sample of 376 households were taken accordingly. Twenty representative samples each for commercial and institutional establishments were selected, and one each for special cases such as hospital, slaughter house and poultry has been assessed. Municipal household waste generation was found to be $0.093 \mathrm{~kg}$ per capita per day which was chiefly composed of $77 \%$ organic, $18 \%$ plastic and $3 \%$ paper. Organic waste has been a major waste for institutions such as schools whereas at governmental and public offices, paper is the predominantly generated waste. Among commercial establishments, shops and restaurants mostly generate organic waste and that for departmental stores has been paper. Though collection system was found to be satisfactory, treatment and final disposal have been unsustainable. Available treatment facilities have been shut down whereas other infrastructural components have been lacking.
\end{abstract}

Keywords: Solid Waste Management, Baseline Survey, Bhaktapur Municipality, Recycling.

\section{Introduction}

Safe disposal and sustainable management of Municipal Solid Waste has been a problem everywhere while solid waste generation rate have been ever-increasing. The nature of solid waste has become diverse. Consequently, increasing rate of solid waste generation, its diversity and unhealthy disposal is creating hazards to human health and environment. Urban settlement around the world is

\footnotetext{
*Corresponding author: Amit Shankar Ranjit

Department of Civil Engineering, Khwopa Engineering College, Bhaktapur, Nepal.

Email: as.ranjit@khec.edu.np

(Received: July 12, 2019 Accepted: November 03, 2019)
}

facing a number of barriers at managing municipal solid waste. Likewise, Bhaktapur Municipality has been confronting with the difficulties in appropriate or sustainable waste management. On the other hand, Solid Waste Management Policy 2011, implemented since 2013 has authorized the local bodies to make plans, policies and to implement them for managing solid waste produced from its municipality (ADB, 2013). The local bodies have been empowered to manage solid waste on its own (SWM Act, 2011).

At present, all municipalities are willing to exercise their power to manage solid waste (Practical Action Nepal, 2008) and are obliged to provide clean and 
healthy surroundings to its residents (SWM Act, 2011). Even though Bhaktapur Municipality has been working satisfactorily for city's sanitation, the local body has been facing problems in solid waste management. Nonetheless, the Municipality intends to work for the establishment of efficient and sustainable SWM system.

Dumping of waste at different locations and recycling of organic waste have been a past practices, while currently the latter has been closed down. Two compost plants were in operation and the organic fertilizer was sold at minimal price to local farmers. On the other hand, at dumping sites, all wastes are simply spread over, compressed and covered with a thin layer of soil.

\subsection{Objective}

Assessment of current Municipal solid waste and its management system was necessary in order to provide the basis for the development of concrete and locality-specific management system (UNEP, 2009). Accordingly, data have been generated as a baseline survey, and this paper aims to determine sector wise municipal waste generation rate, to characterize the municipal solid waste, to know the current practices and issues on solid waste management of Bhaktapur Municipality and to recommend the way forward for sustainable SWM of Bhaktapur Municipality.

\subsection{Limitations}

a) The data generated were one-time data. Seasonal variations and occasional variations were not included.

b) Sewage or liquid waste was not included.

c) Even though street sweeping has been an essential part of Municipal waste management, it was not assessed during this study.

d) Other various large-scale institutional and commercial components have not been included.

\subsection{Study Area}

Bhaktapur Municipality (Fig. 1) is among four municipalities of Bhaktapur District. Bhaktapur district with the geographical range of 27040' 0 " N and $85025^{\prime} 0$ ' $\mathrm{E}$ covers an area of around 6.88 square kilometers at an altitude of $1,401 \mathrm{~m}$ above the sea level and is approximately $13 \mathrm{Km}$ East of Kathmandu. (Webpage Reference)

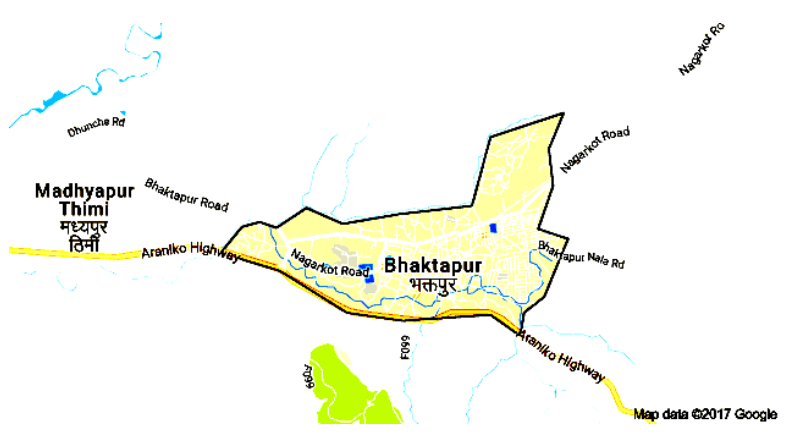

Fig.1. Map of Bhaktapur Municipality.

\subsection{Demographic Information}

The total population of Bhaktapur is 83,893 (Male: 42,947 and Female: 40,946) according to the population census of 2011 with annual growth rate of $1.7 \%$ and the number of households (HH) 13,471 households with the family size of 6 members in an average (CBS, 2012).

\section{Methodology}

\subsection{Research Design and Sample Size Determination}

The method of Arkin and Colton (1963) was employed for sample size determination for household survey, and the sample selection was purposive. The sample size determination formula is given as,

$$
\mathrm{n}=\frac{\mathrm{z}^{2} * \mathrm{~N} * \mathrm{p}(1-\mathrm{p})}{\mathrm{Nd}^{2}+\mathrm{z}^{2} * \mathrm{p}(1-\mathrm{p})}
$$

where,

$\mathrm{z}=95 \%$ confidence level (1.96)

$\mathrm{N}=$ total population size/ Household (17639)

$\mathrm{p}=$ estimated population proportion $(0.5)$

$\mathrm{d}=$ margin of error $(0.05)$

$\mathrm{n}=$ sample size

Sample of 376 households, 20 commercial, 20 institutional and some special cases from hospital, poultry and slaughter house were selected from Bhaktapur Municipality where sample households 
Table 1: Sample size distribution

\begin{tabular}{|c|c|c|c|c|c|}
\hline Ward & Old Wards & Household & Sample Household & Commercial & Institutional \\
\hline 1 & 17 & 2342 & 50 & 2 & 2 \\
\hline 2 & 10,15 & 2273 & 48 & 2 & 2 \\
\hline 3 & 13,16 & 1210 & 26 & 2 & 2 \\
\hline 4 & 12,14 & 1715 & 37 & 2 & 2 \\
\hline 5 & 8,11 & 1249 & 27 & 2 & 2 \\
\hline 6 & 5,9 & 1529 & 33 & 2 & 2 \\
\hline 7 & 6,7 & 1564 & 33 & 2 & 2 \\
\hline 8 & 2 & 1456 & 36 & 2 & 2 \\
\hline 9 & 1,3 & 1669 & 56 & 20 & 20 \\
\hline 10 & 4 & 17639 & 376 & & 2 \\
\hline
\end{tabular}

were proportionately distributed among all 10 wards (Table 1). Most of the household survey was carried out along the main roads and sub roads as they will be more inclusive during waste management programs in the future.

\subsection{Data Collection Method}

Standard questionnaires were prepared for municipality, households, commercial establishments and institutions separately. Structured questionnaire was designed with few open-ended questions which were administered to the sampling units. Key informants were selected for collecting information regarding the existing SWM management system.

A focus group discussion was arranged with the SWM staffs including sweepers, drivers, waste collectors, helpers of Bhaktapur Municipality where problems the SWM staffs were facing during management of waste and other SWM related topics were discussed.
After questionnaire survey, each sampling unit was provided with a standard plastic bag to collect all the waste within 24 hours. The waste was then weighed with the help of calibrated weighing machine (error $\pm 0.05 \mathrm{gm}$ ) and then separated manually into different categories like organic, plastics, paper, metals and so on. Weight of each category was taken. The same procedure was followed for seven days. Other necessary information was collected from relevant literatures, budget, policy and program documents, fiscal year reports, municipality documents and internet.

\subsection{Types of Solid Waste}

Solid waste considered for the survey was based on Tchobanoglous and Kreith (2002) (Table 2).

\section{Results and Discussion}

\subsection{Household Waste Characterization}


Table 2: Types of Solid Waste

\begin{tabular}{|c|l|l|}
\hline S.N. & Source of Solid waste & \multicolumn{1}{c|}{ Type of solid waste } \\
\hline 1 & Household waste & $\begin{array}{l}\text { food waste, discarded food, paper plastics, textiles, leather, yard waste, } \\
\text { wood, glass, tin cans, aluminium, discarded plastic plates, shoes, slippers, } \\
\text { cloth piece, broken plugs, drug bottles, bags, broken bangles, mosquito } \\
\text { coils }\end{array}$ \\
\hline 2 & Commercial waste & $\begin{array}{l}\text { paper, plastics dust, food waste, glass, metals packing materials, discarded } \\
\text { and spoiled pens, chalk pieces, waste from pencil scarping, discarded food, } \\
\text { food wrappers }\end{array}$ \\
\hline 3 & Institutional waste & $\begin{array}{l}\text { paper, plastics dust, food waste, glass, metals packing materials, discarded } \\
\text { and spoiled pens, chalk pieces, waste from pencil scarping, discarded food, } \\
\text { food wrappers }\end{array}$ \\
\hline
\end{tabular}

An average of $0.093 \mathrm{~kg}$ per capita per day waste was generated from household sector. The highest per capita waste generation per day was from ward 6, 7 and 8 which are $0.130,0.107$ and 0.103 respectively. The lowest per capita waste generation per day was found to be from ward 10 which is 0.068 (Table 3 ).

Table 3: Per-capita household waste (Kg/day)

\begin{tabular}{|c|c|}
\hline Wards & Per capita waste per day \\
\hline 1 & 0.081 \\
\hline 2 & 0.095 \\
\hline 3 & 0.100 \\
\hline 4 & 0.071 \\
\hline 5 & 0.099 \\
\hline 6 & 0.130 \\
\hline 7 & 0.107 \\
\hline 8 & 0.103 \\
\hline 9 & 0.080 \\
\hline 10 & 0.068 \\
\hline Average & 0.093 \\
\hline
\end{tabular}

The municipal household waste was found to be $77 \%$ organic, $3 \%$ paper, $18 \%$ plastic, $1 \%$ glass and $1 \%$ small amount of other wastes (Fig. 2). The highest waste generating wards include Wards 2, 1 and 6, and lowest waste generating wards were Wards 3, 5 and 4. As compared to the data from the year 2012 (KC and Karmacharya, 2012), which was $83 \%$ organic wastes, $10 \%$ plastics, $4 \%$ paper, $0.6 \%$ glasses, $0.80 \%$ textiles, $0.30 \%$ others, the plastic content in the waste has increased by $8 \%$ while contribution of organic waste in the total waste has been reduced.

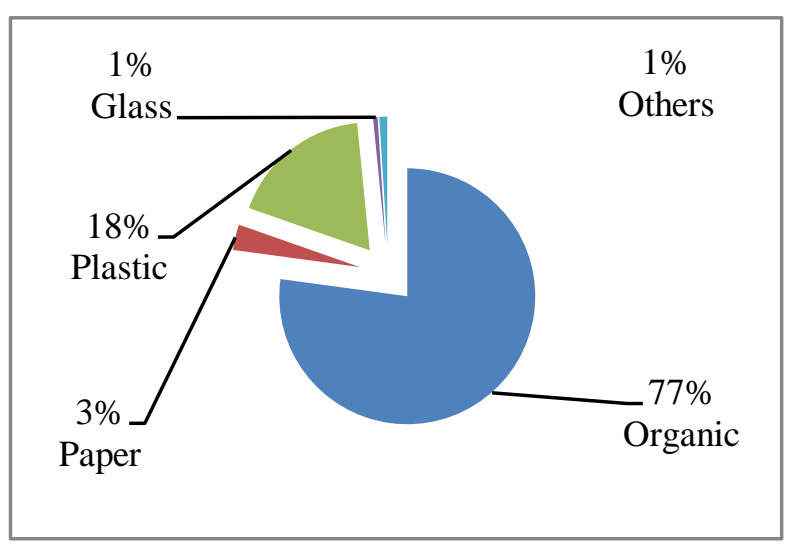

Fig. 2. Household Waste Composition. 
Table 4: Average commercial waste per day $(\mathrm{Kg})$

\begin{tabular}{|l|l|l|l|l|l|l|l|l|l|l|l|}
\hline Sectors & \multicolumn{9}{l}{ Average waste per day } \\
\hline Ward & $\mathbf{1}$ & $\mathbf{2}$ & $\mathbf{3}$ & $\mathbf{4}$ & $\mathbf{5}$ & $\mathbf{6}$ & $\mathbf{7}$ & $\mathbf{8}$ & $\mathbf{9}$ & $\mathbf{1 0}$ & Average \\
\hline Shops & 0.781 & 0.155 & 0.413 & 0.106 & 0.180 & 0.352 & 0.197 & 0.132 & 0.354 & - & 0.297 \\
\hline Restaurants & - & 20.262 & - & - & - & - & 1.513 & 0.683 & 3.646 & 4.941 & 6.209 \\
\hline Hotels & - & - & - & - & - & - & - & - & - & - & - \\
\hline $\begin{array}{l}\text { Department } \\
\text { store/mini mart }\end{array}$ & - & - & - & - & 20.431 & - & - & - & - & - & 20.431 \\
\hline
\end{tabular}

\subsection{Commercial Waste}

The 20 samples from commercial waste assessment were carried out at shops, restaurants, hotels and a department store (Table 4). The average waste generation per day was seen higher at departmental stores, which has been $20.431 \mathrm{~kg}$ per day followed by $6.209 \mathrm{~kg}$ per day in case of restaurants. However, since the samples of restaurants from most of the wards were of smaller scale, the amount of generated waste was found to be comparatively lesser than those large scale restaurants.

Waste generation from shops contained 50\% organic, $14 \%$ paper, $24 \%$ plastic, $5 \%$ glass and $8 \%$ other waste materials (Fig. 3). The average waste generation from shops is $0.655 \mathrm{~kg}$.

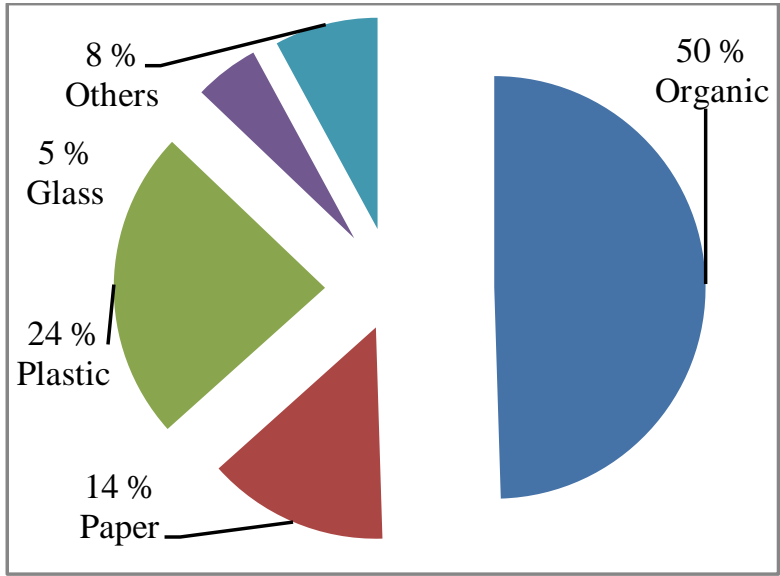

Fig. 3. Commercial Waste Composition (Shops).
The average waste generation from restaurant sector was found to be $7.38 \mathrm{~kg}$ per day. The waste majorly consists of $80 \%$ organic followed by $10 \%$ paper, $4 \%$ plastic and 6\% glass (Fig. 4). Since the commercial sector is diversified, a more comprehensive survey needs to be carried out in near future which may possibly generate more accurate data.

Almost all of the wastes produced from department store/mini market were paper and contained less plastics. This can be because of high use of paper carton boxes as packaging materials and less use of plastic wrappers and plastic bags. Most of the departmental stores are using reusable bags.

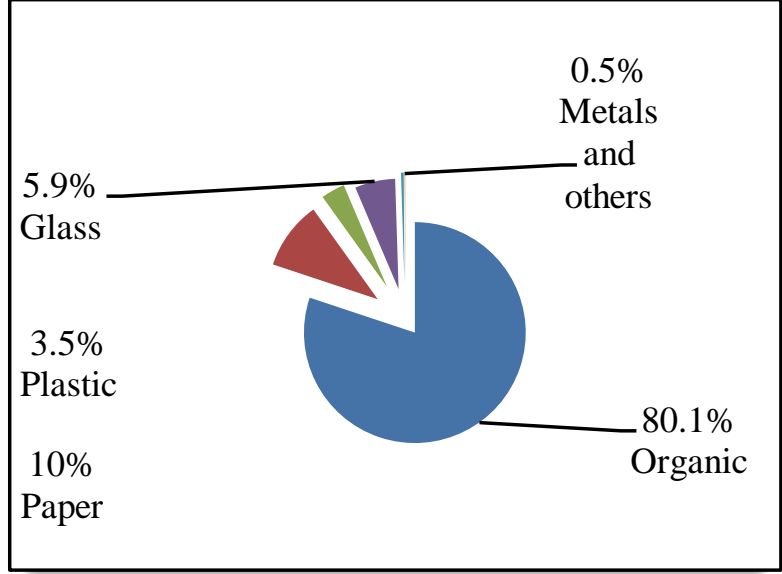

Fig. 4. Commercial Waste Composition (Restaurants). 


\subsection{Institutional Waste}

The 20 samples from institutional sectors were carried out (Fig. 5 and 6) from school, office, bank and a child care (Table 5). Among them, school generated more waste than other sectors, which is $2.164 \mathrm{~kg}$ per day.

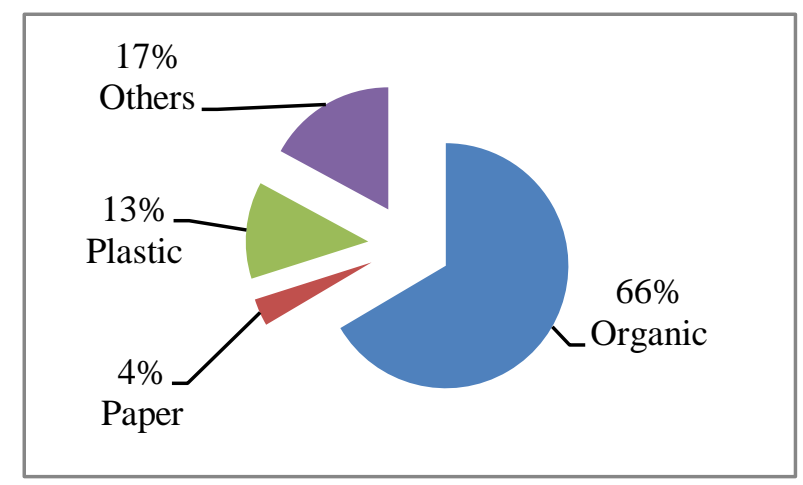

Fig. 5. Institutional waste composition (Schools).

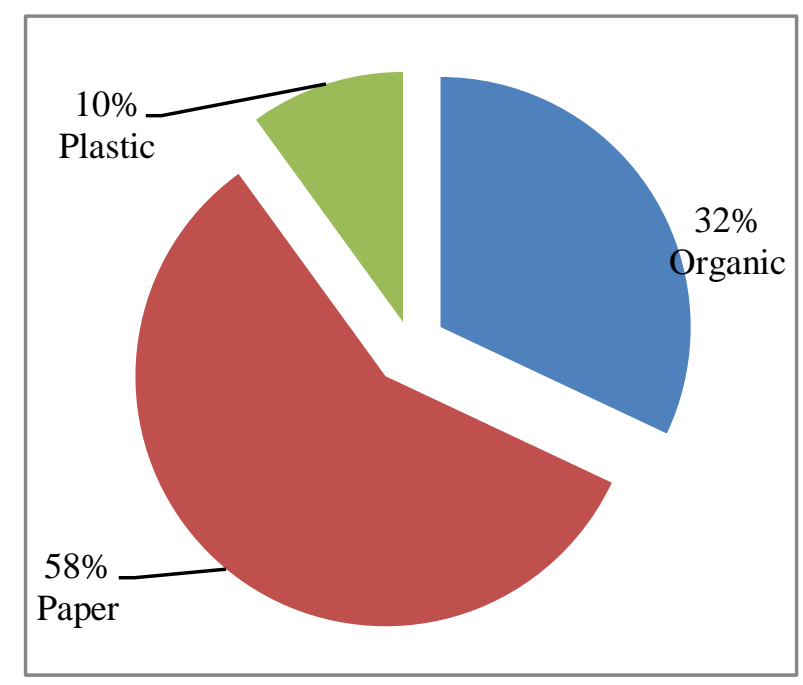

Fig. 6. Institutional waste composition (Offices).

Table 5: Average institutional waste per day $(\mathrm{Kg})$

\begin{tabular}{|l|l|l|l|l|l|l|l|l|l|l|l|}
\hline Sectors & \multicolumn{1}{|l|}{ Average waste per day } \\
\hline Ward & $\mathbf{1}$ & $\mathbf{2}$ & $\mathbf{3}$ & $\mathbf{4}$ & $\mathbf{5}$ & $\mathbf{6}$ & $\mathbf{7}$ & $\mathbf{8}$ & $\mathbf{9}$ & $\mathbf{1 0}$ & Average \\
\hline School & - & 3.417 & 2.665 & - & - & - & - & - & 0.410 & - & 2.164 \\
\hline Office & 0.161 & - & 0.540 & 0.307 & - & 0.272 & 0.106 & 0.119 & - & - & 0.251 \\
\hline Bank & - & - & - & - & - & - & 0.501 & - & - & - & 0.501 \\
\hline $\begin{array}{l}\text { Child } \\
\text { Care }\end{array}$ & - & - & - & - & - & - & - & 0.62 & - & - & 0.62 \\
\hline
\end{tabular}

\subsection{Other Waste Streams}

\subsubsection{Hospitals}

Siddhi Smriti Hospital located in Adarsha, Bhaktapur was sampled purposively as a special waste generator. About $28 \%$ of the waste was found to be hazardous, while $65 \%$ was general (Table 6, Fig. 7 and 8).

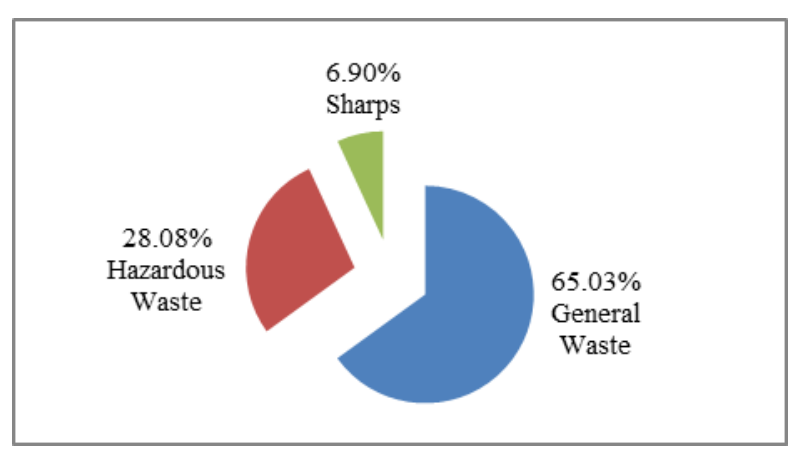

Fig. 7. Types of Wastes Siddhi Smriti Hospital. 


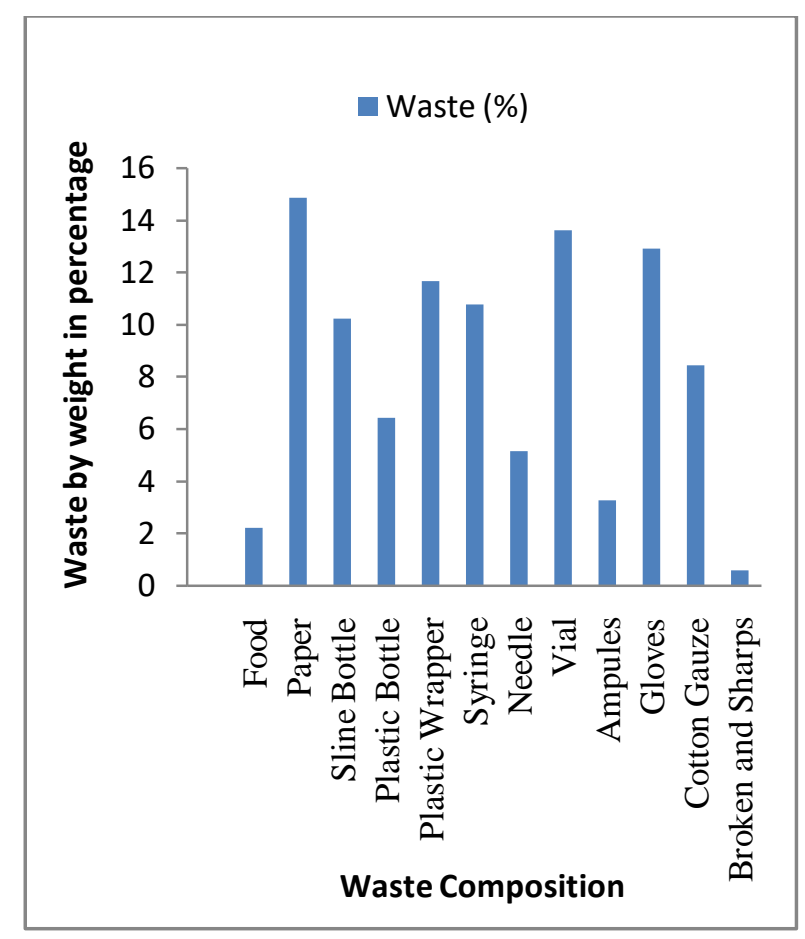

Fig. 8. Waste characterization of Siddhi Smriti Hospital.

Table 6: Waste types of hospital

\begin{tabular}{|l|l|l|}
\hline Waste Type & Percentage & $\begin{array}{l}\text { Weight } \\
(\mathrm{Kg})\end{array}$ \\
\hline General Waste & $65.03 \%$ & 915.259 \\
\hline Hazardous Waste & $28.08 \%$ & 395.152 \\
\hline Sharps & $6.90 \%$ & 97.047 \\
\hline Total & $100 \%$ & 1407.458 \\
\hline
\end{tabular}

\subsubsection{Poultry}

The major waste generated includes excreta and broken eggs. The waste is collected once in a year. Approximately $150-200 \mathrm{~kg}$ of manure is collected per year, whereas broken eggs are not detectable when waste is collected. After the waste is collected, it is sold. The waste content from broken eggs is negligible since it is consumed by fowls. Other types of wastes are negligible.

\subsubsection{Slaughter House}

The waste generated include litter (bedding materials such as saw dust, wood shavings, straw, peanut or rice hulls), excreta, bones, blood and waste meat products. Waste is collected once every
2 or 3 days. Approximately during slaughtering of one buffalo generates $15 \mathrm{~kg}$ of bones, 1.5 liters blood/liquid waste and $10-12 \mathrm{~kg}$ waste meat products. The excreta is exchanged with feed (grasses and straw) for buffaloes from farmers.

\subsection{Existing Solid Waste Management System}

\subsubsection{Collection}

Bhaktapur Municipality has been employing door to door collection method for household waste. Tricycles with separate compartments for biodegradable and non-biodegradable wastes are used for collection of segregated waste. The tricycles collect waste from almost all wards every second day in the morning.

Waste from street sweeping and waste collected on some parts of road are collected by vehicles. This waste is not separated rather it is mixed.

Major touristic areas of Bhaktapur receive collection services throughout day. There is separate provision of staffs of picking waste all day. These areas are also provided with dustbins to collect the waste so they remain cleaned all day.

\subsubsection{Transfer Station and Transportation}

Currently there is no any transfer station in the Municipality. The collected wastes from all the wards are transported to the dumping site allocated by Municipality.

\subsubsection{Treatment and Final Disposal}

With the closure of composting facilities, currently there are no treatment facilities in Bhaktapur Municipality. Wastes from all sources including special waste generators are landfilled.

\subsection{Resource Recovery}

\subsubsection{Recycling}

Recycling center operated by the Municipality is not available. Yet few private recycling centers are in operation to buy paper, plastics, bottles and metals from the city residents at minimal price, and these materials are sold outside of the city. From this survey, $36 \%$ of respondents were found to be 
segregating the waste.

In addition, the SWM staffs of Bhaktapur Municipality especially responsible for final disposal are permitted to segregate the waste and generate income accordingly.

\subsubsection{Composting}

Newar community of Bhaktapur is traditional practitioner of composting; the age-old sustainable practice has almost disappeared. This study showed that only $9 \%$ of the respondents have still been practicing composting at household level. Bhaktapur Municipality had been operating two central level composting plants; however, both have been shut down due to lack of space and issues of public hygiene.

\subsection{Public Awareness and Community Mobilization}

Bhaktapur Municipality is using audio as a major tool for creating public awareness regarding solid waste management. The waste collecting vehicles have been playing different slogans about need and importance of source segregation of waste and many other solid waste management related topics. However, its effectiveness is yet to be measured.

Bhaktapur Municipality had provided each household with two separate bins for collection of biodegradable and non-biodegradable waste. But the program did not succeed due to lack of public awareness. Similarly, after 2072 B.S. Bhaktapur Municipality provided two separate bins with color code; green for biodegradable and red for nonbiodegradable waste collection at certain area, and has recently extended the program to all areas of Bhaktapur Municipality. The effectiveness of this program is still to be known.

In addition, Bhaktapur Municipality had also provided compost bins to the locals of Libali to promote household composting. This program too ended without significant changes in the locality because of lack of public awareness.

\subsection{Institutional and Financial Aspects}

\subsubsection{Organizational Structures}

Bhaktapur Municipality has been taking the full responsibility of waste management. Bhaktapur Municipality has an Environmental section under Project Monitoring and Evaluation Committee headed by Chief Executive Office under the supervision of Mayor. All the activities related to waste management is undertaken by Environment section. As waste management is a topmost priority of Bhaktapur Municipality, organizational structure for solid waste management activities has been well set-up. Municipal waste collection is very effective in all the wards. $96 \%$ of respondents are satisfied with the waste management system of the Municipality. The Municipality follows various acts and regulations formulated by Nepal government and other relevant authorities relating to solid waste management.

\subsubsection{Human Resource and Capacity}

Bhaktapur Municipality employs a total of 201 staffs for solid waste management which includes city inspector, ward inspector, drivers, sweepers and so on. There are enough staffs for solid waste management but Municipality still lacks technical and semi-technical. Currently, Bhaktapur Municipality has sufficient equipment for solid waste management activities.

\subsubsection{Budget and Expenditure}

As stated by City Inspector, the expenditure of Municipality for waste management is approximately Rs 9.25 per $\mathrm{kg}$ of waste and waste collection was nearly 28 tons per day as per previous data. Municipality allocates significant share of budget for solid waste management activities which amounts to 7 percent of the total budget during the fiscal year 2074/75 and 4.15 percent during the fiscal year 2074/75, according to the Municipality source.

\subsubsection{Revenue}

Bhaktapur Municipality charges Rs. 360 per annum as solid waste management service charge to each household. However, this study has shown that $68 \%$ of the respondents are willing to continue the 
payment for solid waste management service charge and $77 \%(\mathrm{n}=416)$ of respondents are willing to pay more than NRs. 100 per month.

\subsection{Major Problems and Issues}

Although Bhaktapur Municipality is working well in sanitation sector, it still faces huge challenges in disposing the waste safely. The Municipality urgently needs a sanitary landfill. Public resistance against SWM infrastructure building has been a hurdle. Increasing population, lack of awareness, insufficient resource recovery facility has been other impediments. Though Municipality has provided separate bins with color codes for collection of biodegradable and non-biodegradable wastes, only $39 \%$ of the respondents have received the bins. Segregation of waste at the source has been practiced by only $42 \%$ of the respondents. Source segregation of waste is found to be practiced well by the people of wards $2,3,8,9$ and 10 , whereas people from wards $4,5,6$ and 7 are discarding mixed waste to the collection tricycles. $65 \%$ of respondents think that it is the responsibility of Municipality to segregate the waste.

\section{Conclusion and Recommendation}

This baseline study on solid waste management of Bhaktapur Municipality has shown that the waste generation rate of Municipal household was found to be $0.093 \mathrm{~kg} /$ person/day. Commercial and institutional wastes have been categorized in accordance to different types of establishments such as shops, schools, cafeteria, restaurants and office set-ups and so on. Households generate about 77 percent of organic waste while plastic waste was found to be about 18 percent. Organic wastes dominate the total waste stream for shops and restaurants and other institutions such as schools. However, paper is the major waste in departmental store and office set-ups. Waste generation rate at hospitals is found to be $15.428 \mathrm{~kg}$ per day, whereas slaughter house and poultry wastes are partially self managed. Privately owned recycling centers have been reluctant to disclose all the information.

Though the performance of the Municipality seems to be better in collection of waste and is successful in satisfying $70 \%$ of its people, it still lacks a sanitary landfill space for appropriate disposal of waste. The present system of waste disposal is causing severe damage to the aquatic ecosystem and the environment. On the other hand, level of awareness of the residents seems to be lacking, and necessary solid waste management infrastructural components such as transfer station and compost plant have been shut down.

Sensitization on waste management and revival of composting plants and establishment of recycling centers has been suggested. It is essential to implement Solid Waste Management Act and guidelines strictly and conduct regular monitoring. Waste management model programs (pilot projects) need to be implemented. Waste collection in segregated form needs to be initiated in the core wards. Waste collection fee needs to be revised, and fee scheme shall be categorized as per waste generation rate of different establishments. Municipality need to construct MRF or treatment facilities, where waste can be segregated, recycled and recovered. Dumping site (sanitary landfill) needs to be allocated at a place having lesser environmental impacts. Municipality needs to monitor their vehicles for proper maintenance to minimize unnecessary repair costs.

\section{References}

[1] Arkin, H and Colton, R (1963). Table for Statistics. New York: Barnes and Noble Publication.

[2] Asian Development Bank (2013). Solid Waste Management in Nepal: Current Status and Policy Recommendations. Mandaluyong City, Philippines.

[3] Brief Introduction, Bhaktapur Municipality. http://bhaktapurmun.gov.np/en/node/4 (extracted on 1st December 2018)

[4] CBS (2012). National Population and Housing Census 2011 (National Report). Government of Nepal, National Planning Commission Secretariat, Kathmandu, Nepal.

[5] K.C., U and Karmacharya, S (2012). Report of Solid Waste Management Baseline Study in Bhaktapur Municipality. Solid Waste Management Technical Support Center, Lalitpur, Nepal. 
[6] Practical Action Nepal (2008). Best Practices on Solid Waste Management of Nepalese Cities. European Union Under the EC Asia Pro. Eco II Program, Lazimpat, Kathmandu, Nepal.

[7] Solid Waste Management Act (2011). Government of Nepal.

[8] Tchobanoglous, G. and Kreith, F. (2002). A Handbook of Solid Waste Management. McGrawHill Companies, USA, Second Edition.

[9] UNEP (2009). Developing Integrated Solid Waste Management Plan, Training Manual. United Nations Environment Programme, Division of Technology, Industry and Economics International Environmental Technology Centre, Osaka/Shiga, Japan. 